\title{
Election Commentaries
}

Contents

Introduction

66

Richard Crisp and Will Eadson

Crisis? What crisis? Housing policies from the main parties in England, Scotland and Wales for the 2015 general election

67

Ian Cole

Peering beyond the cliff-edge: what role for the voluntary sector in post-election United Kingdom?

Chris Dayson

Urban planning dilemmas: where next?

Karen Escott

Regional development: a casualty of the general election?

Steve Fothergill

The $\mathbf{2 0 1 5}$ general election and the impending crisis in local public services

Tony Gore

Migration policy: stuck in a rut?

David Robinson 


\title{
Introduction
}

\author{
Richard Crisp and Will Eadson* \\ CRESR, Sheffield Hallam University
}

With the 2015 UK General Election exactly two weeks away, PPP presents a specially commissioned series of commentaries on six key policy domains: planning, regional policy, housing, the voluntary sector, migration and local public services. Each has been put under the lens by a national expert to reflect on the challenges faced, and the adequacy of proposals put forward, by the parties contesting the election. The editors deliberately left the brief vague to enable the six contributing authors to explore their particular policy domain as they saw fit to best capture the dynamics of the debate and highlight the issues that matter. The result is a set of reflections that are personal and, at times, deeply-felt but always rooted in longstanding academic expertise in each field.

Common themes that emerge across the six commentaries include the inexorable move towards devolution at national and sub-national level, the consensus on fitting policy around the financial straightjacket of 'Austerity' and the growing complexity of designing policy in an ever more fragmented political arena. Most notably, contributors present a consistent picture of risk and instability from, for example, the ever present spectre of further funding cuts to the voluntary sector (Dayson), the potential loss or dilution of the effective Regional Growth fund (Fothergill) and the critical state of local public service provision (Gore). The message on migration is particularly stark: Robinson explains how the four highest polling parties offer little for those in search of a more humanitarian or even just an evidence-based migration policy.

But the picture is not uniformly bleak and there are also glimmers of opportunity. Cole draws on the proposals of the smaller parties to present a more progressive housing policy that seems ever less fanciful as the UK enters what looks like a new era of coalition building. And despite contestation around the detail, Escott argues that the major parties (excluding UKIP) have relatively strong energy and conservation policies, providing some small hope for solutions on climate change and the environment.

The reflections of contributors are laced with the uncertainty that comes from an election where the outcome is likely to depend as much as on post-election bargaining behind closed doors as the popular vote. But in this fevered and increasingly bitter preelection campaigning period we hope these commentaries cut though some of the murk, dogma and populism to critically examine the nature and purpose of public policy. At the very least, it might frame the debates that need to inform policy once the dust of the 2015 General Election settles. And just as importantly, it could even help wavering PPP readers in the UK decide where to put their cross on election day.

* Correspondence Address: CRESR, Sheffield Hallam University, Unit 10, Science Park, Howard Street, Sheffield, S1 1WB. Email: ppp-online@shu.ac.uk 


\title{
Crisis? What crisis? Housing policies from the main parties in England, Scotland and Wales for the 2015 general election
}

\author{
Ian Cole* \\ CRESR, Sheffield Hallam University
}

In an earlier draft of this paper I had suggested that a sense of perspective proportion would be in order in terms of how far housing issues would influence the outcome of the forthcoming general election. I claimed that housing might figure more prominently than in recent elections, but would still be a secondary topic compared to issues such as the economy, the NHS and immigration. So much for my punditry. I am now revising the paper on the very day a major party placed an issue of housing policy at the heart of its 'offer' to the electorate. And it is the party that has presided over an intensifying housing crisis during the past five years: the Conservative Party, turning back the years and embracing the right to buy again to swing those marginal voters, just like it did in the 1980s. We will return to this shortly.

The context of the 2015 election is of course more complex than before, with the devolution of policy (to different degrees) to Scotland, Wales and Northern Ireland, and the rise in popularity of the Scottish National Party, UKIP and the Green Party. In this brief summary I will offer a personal view on some key areas of policy difference, and for reasons of space will confine my comments to England, Wales and Scotland. I will also concentrate on the policies of the only two parties which will definitely be part of any coalition that may emerge after May $7^{\text {th }}$ - the Conservative Party and the Labour Party.

In line with the long standing shift in public expenditure from housing production to housing consumption - from 'bricks to benefits' - the period of Coalition government since 2010 has reinforced the tendency for 'housing' policy to become subsumed under welfare policy. In this light, the crispest difference between the political parties on any housing-related issue is over the Removal of the Spare Room Subsidy, or 'bedroom tax'. The Conservatives would retain it; the Liberal Democrats would reform it, all the other parties would repeal it. For the Labour Party in particular, the potential political dividend over repeal is inviting, as it offers a rare opportunity to unravel one part of the welfare reform agenda that is widely seen as unpopular and unfair. The fact that the redesignation of the name of the policy as the 'bedroom tax' has stuck (in a similar way that that the Community Charge became forever known as the poll tax) suggests that the Opposition has won the 'discourse war' on this issue, if not on many others. This contrasts, however, with the rather deafening silence from the Labour Party on other controversial aspects of welfare reform (such as the application of increasingly punitive benefit sanctions).

The cost of repealing the bedroom tax would also be relatively modest. Revising his previous analysis (Wilcox, 2014), Professor Steve Wilcox, for example, has recently calculated that the annual cost (net of the transitional support) would be in the region 
of around $£ 250$ million a year, set against a total welfare bill (spending on DWP benefits, child benefits and tax credits) of around $£ 210$ billion in 2013/14 (OBR, 2014). One can therefore understand why Ed Miliband has committed a future Labour Government to repeal the legislation in its first budget. It is less clear at the time of writing whether the Conservative Party would make further inroads into acquiring savings from the bedroom tax. It is already committed to removing Housing Benefit from unemployed people under the age of 21, freezing working age benefits for two years and reducing the overall benefit cap from $£ 26,000$ to $£ 23,000$ a year. Even taking account of these measures, the IFS has calculated that the Conservatives have not specified how $£ 10$ billion of the planned $£ 12$ billion cuts per year in the welfare bill for working age adults will be sought.

When one moves from counting existing bedrooms to counting future houses, the picture becomes more blurred. There is broad consensus that there is a housing shortage, which has an impact on access to home ownership, increased reliance on the private rented sector and more pressure on social housing. Most of the parties have, however, said far less about policies to deal with some of the other impacts (increased overcrowding, greater use of temporary accommodation and rising homelessness).

The fate of the first time buyer has, as ever, a mesmerising effect on the parties' positioning on housing policy. For any putative home owners scanning the policy headlines rather than underlying content there is an embarrassment of riches from the Conservatives: extending Help to Buy, introducing a 'starter homes' programme and a Help to Buy ISA, and pressing on with a rent to buy programme. Above all, there is the extension of the Right to Buy to 1.3 million households in the housing association sector, in a blatant attempt to rekindle the magical political dividend of the Thatcher era. But the chances of history repeating itself are slim. Housing associations are legally constituted - as Community Benefit Organisations - in a different way from local authorities. Entry into home ownership - even nurtured by large discounts - is, I suspect, seen as a more hazardous option than it was, and those long-standing housing association tenants who stand to gain most are less likely to be in work and have more diverse demographic attributes (and, perhaps, voting preferences) than the council tenants of the 1980 s.

The policy of replacement is to be partly financed by gradual sales of the most expensive council properties - thereby reducing the stock of relatively affordable rented housing by two in order to secure a gain in ownership for the sitting tenant of just one. In this Alice in Wonderland world it seems almost pedantic to point out that it will not be at all helpful for future labour mobility, which requires a vibrant rented sector. It will harm the prospects of many 'decent, hard working families' we hear so much about elsewhere.

The Conservatives' other incentives to expand home ownership are the usual combination of indirect subsidy support and deregulation. These are combined, for example, in the starter homes programme, aiming to build 200,000 homes for first time buyers under 40 , to be sold at 20 per cent below open market value (and removing some planning obligations on developers in the form of section 106 and the community infrastructure levy). The Help to Buy equity loan scheme has already been extended to 2020 and the 2015 Budget introduced the Help to Buy ISA, contributing 25 per cent of money saved in deposits by first time buyers up to $£ 3,000$. No overall future housebuilding target is set, excusing at least one potential hostage to fortune.

With so many options to buy, will generation rent now wither away and the nation of home owners return, if the Conservatives succeed? The key question here is whether any increased developer and lender activity in response to these measures will produce net additions to future housing supply or simply substitute some kinds of developments 
for other, more profitable, ventures, in a context of continuing scarcity. History would suggest that some scepticism is in order about the impact of such measures on increasing overall supply.

The Labour Party proposals on housing supply include setting up a Future Homes Fund from the money earmarked for the Help to Buy ISA. Labour is committed to building 200,000 new houses per year by 2020. A quarter would be met by local authorities and housing associations, and a similar proportion by SME builders, selfbuild groups and institutional investment in the private rented sector. In the mania for creating initiatives with a 'Help to...' prefix, this will, inevitably, be called Help to Build. The move away from a reliance on the larger housebuilders makes sense given recent trends, which have seen profitability ratios increasing far faster than any increases in volume.

Local authorities will be able to fund new building from unused borrowing capacity in their housing revenue accounts. These measures will have limited effects. But Labour has ducked one big question - allowing local authorities much greater license to borrow to invest. One key difference between the two main parties is that capital investment is excluded from the Labour Party's plans for deficit reduction and a balanced budget by 2020 , while it is included in the Conservatives' plans. Despite this, the Labour Party remains reluctant to commit to remove constraints on capital investment in housing to make a significant in-road into rebalancing the housing away from consumption and towards production.

The most obvious change in the English housing market in the past ten years has been the growth of the private rented sector from ten per cent to 19 per cent over the ten years to 2013/14, and from 21 per cent to 48 per cent of households aged 25 to 34 (DCLG, 2015: Figure 1, para 2.14). The sector is complex, diverse and fluid, which places demands on how to target any new policy measures. But the position of the two main parties does not offer an immense amount for generation rent, even though one might argue that there is a considerable political dividend at stake here. The Conservatives steer clear of more regulation, while 'encouraging' landlords to offer longer term tenancies, and encouraging 10,000 rent-to buy properties to be built through low cost loans. Labour proposes to make three year tenancies the norm, place a ceiling on rent rises banning agents from charging fees to tenants and introducing a 'national register' of landlords. There is no mention of changing the HB reforms affecting private tenants, even though the cuts here have been more than three times greater than those brought about by the bedroom tax.

In terms of the other parties, the Liberal Democrats have advocated a target of 300,000 homes a year by 2020 , at least ten garden cities, a housing investment bank to fund long-term capital for new settlements, and an interesting rent-to-own policy, in which tenants' rents gradually build up ownership on the property over a thirty year period. One of the most radical suggestions, given the silence on the issue from the two main parties, was the suggestion by Vince Cable in 2013 to introduce an annual land value tax for home owners, but this has apparently now been kicked into that overcrowded area in housing policy - the long grass.

In advance of their manifesto, the policy priorities of the Scottish National Party can be gauged from the measures taken by the Scottish Parliament in the past three years the use of transitional payments to nullify the impact of the bedroom tax, the removal of the right to buy, and increased investment in building council housing. In addition, everyone who is unintentionally homeless has been classified as in priority need. These measures are likely to form the basis of any post-election bargaining.

UKIP has apparently discovered the existence of something called brownfield sites, as the issue is at the centre of the housing component of their manifesto, which 
includes a commitment to build one million houses on such sites by 2025 . In a clear attempt to capture the rural Tory vote, protection of the green belt is a priority and planning permissions on large-scale developments can be removed by local referenda, beyond a specified threshold. UKIP has also discovered the previously neglected importance of grandparents, in proposing that a 'test' of local priority for social housing will be made, that will depend on a parent or grandparent being born in the area. The UKIP over-riding priority is clear in their suggestions for restricting the right to buy and help to buy - it would be removed from foreign nationals, except those who have served in the armed forces. One might wish to ponder how far that will really get to the root of the country's housing crisis.

If you need to be roused from your slumbers from this detail and if you have a sense that much of what has been covered so far concerns different techniques for rearranging the deckchairs on the Titanic of housing markets in Britain, then the policies of the Green party may wake you up. It is of course hardly novel (and almost tautological) for the mainstream party likely to garner the least seats at the election to have the most radical policies. Certainly the measures advocated by the Greens address what many analysts identify as some of the long standing structural peculiarities of housing markets in Britain - over-emphasis on owner-occupation, serious lack of investment in social housing, an inefficient, expensive and ill targeted housing benefit regime, and an unduly permissive regime for the private rented sector. And there is a straightforward element to the proposals that exposes the rather tangled suggestions made by other parties.

In short, the Greens propose to:

- end the right-to-buy and replace it with a right-to-rent policy

- scrap mortgage interest relief for buy-to-let mortgage holders

- cap rent rises at the rate of inflation and establish a Living Rent Commission

- build 5000, 000 new socially rented homes by 2020

- lift the borrowing cap for local authorities, funding an estimated 600,000 extra council properties

- abandon the classification of intentional homelessness by local authorities

- end the use of hostel and B and B provision for homeless households

- promote housing co-operatives and self-build schemes

- phase out assured tenancies

- introduce new council tax bands

- apply new standards for accessibility, space and facilities insulation and energy efficiency.

Imagine, just for a moment, if the Labour Party/Liberal Democrats/SNP/Plaid Cymru were to adopt such a radical set of policies as part of coalition building. While it might please a handful of housing academics (me and my friends), would it constitute another of those electoral suicide notes ${ }^{1}$ in housing terms? I wonder. From the early 1980s onwards, the Labour Party has been haunted by the political success of the Right to Buy achieved by the Thatcher governments, and as a result council housing as whole was seen by New Labour as a political embarrassment, redolent of old Labour, leaden municipalism and an outmoded option for younger households.

But things have changed: the average young voter has more experience of renting in the private sector than of home ownership; and private renting is usually more expensive than social housing, and standards of management, property condition and repairs in the sector vary widely in quality. The mixed experiences of private tenants might make them much more interested in proposals for a more affordable, better regulated and more accountable rented market. Rather than a suicide note, I would 


\section{p. 71. Election Commentaries}

contend that a policy like this could garner a great deal of electoral support. It could tap into the lived realities of 'generation rent' voters in a similar way that right to buy did for many council tenants thirty years ago. Well, one can dream....at least until May $7^{\text {th }}$.

\section{Notes}

1 Following Gerald Kaufman's description of Labour's 1983 manifesto as 'the longest suicide note in history.

\section{Acknowledgements}

Many thanks to Ken Gibb and Kim McKee for their help, and to Rich Crisp and Will Eadson for their constructive advice.

* Correspondence Address: Professor Ian Cole, CRESR, Sheffield Hallam University, Unit 10, Science Park, Howard Street, Sheffield, S1 1WB. Email: i.d.cole@shu.ac.uk

\section{References}

Department of Communities and Local Government (DCLG) (2015) English housing survey headline report 2013 to 2014. London: DCLG.

Office for Budget Responsibility (2104) Welfare Trends. London: OBR.

Wilcox, S. (2014) Housing Benefit Size Criteria: Impacts for Social Sector Tenants and Options for Reform. York: Joseph Rowntree Foundation. 


\title{
Peering beyond the cliff-edge: what role for the voluntary sector in post-election United Kingdom?
}

\author{
Chris Dayson* \\ CRESR, Sheffield Hallam University
}

This paper reflects on the past five years of government and public policy for the voluntary sector in the UK and considers the post-election prospects for the sector between 2015-20. Its central argument is that that the predicted disjuncture in 2010 was even more significant than expected, largely due to the swingeing scale of public spending cuts at a local level, and the likelihood that further cuts on a similar scale will frame the sector's prospects going forward. However, the paper also argues that these cuts have necessitated a shift in focus in public service provision towards prevention, and this presents an opportunity for the sector to reposition itself as a central component of the 'solution' to radically reduced public expenditure over the next five years (and longer).

\section{0: A neoliberal disjuncture for voluntary sector policy}

Five years ago a similar commentary by Crowe et al (2010) in this journal predicted that 2010 would mark a significant 'disjuncture' in the development of the voluntary sector in the UK. The preceding ten years had been marked by unprecedented growth and 'mainstreaming' of the sector, and despite pre-election rhetoric from all the main parties that the sector would remain central to key agendas, the paper argued that the period 2010-15 would be markedly different in three key areas: the relationship between state and society, resources and scale, and equity and disadvantage.

This prediction has proved largely accurate. The Conservative-Liberal Democrat Coalition has overseen a significant scaling back of the large-scale, centrally funded voluntary sector programmes that marked the 'New' Labour period, with more focus on policies that promote citizen-led social action and less on targeting spatial or individual disadvantage or the empowerment of marginalised groups. At the same time, and despite the quiet withering of the initial 'Big Society' rhetoric, the Government's vision for the sector has been repositioned more overtly along neoliberal lines. This includes an emphasis on voluntary and community organisations playing roles in arenas which should be vacated by state intervention; and facilitating broader relationships with financial markets, particularly where this can lever private and quasi-private equity to support the sector's delivery of public services.

The 2010 commentary also predicted the sector would undergo a period of rationalisation and contraction following the election due to the ongoing effects of recession and anticipated public expenditure reductions. These were expected to fall most heavily on smaller and medium-sized organisations, particularly those working in disadvantaged neighbourhoods in the northern regions of England, Scotland and Wales. Although the commentary did not place a figure on the expected scale of this 
rationalisation, what it could not have foreseen was the swingeing nature of the spending cuts announced in the 2010 post-election 'emergency budget' and the scale of the government's ongoing deficit reduction programme, the impacts of which on the sector have been profound. Estimates by NCVO (2014) indicate that between 2010/11 and $2011 / 12$, total income from government to voluntary sector organisations fell by $£ 1.3$ billion in real terms. The impacts were felt most by organisations providing social services, who received $£ 361$ million less than the previous year; and employment and training organisations, who received over $£ 230$ million less. At the same time many voluntary organisations, particularly those providing support in areas such as poverty relief, advice and guidance, and homelessness, have reported increasing demand for their services. An associated trend has been the growth in food banks, with the Trussell Trust network alone reported to have expanded from providing emergency food for 26,000 people in 2008/09 to over 913,000 people in 2013/14 (Trussell Trust, 2014).

These factors combined suggest the disjuncture has been far greater than could have been expected in 2010 and although the sector's many representatives continue to lobby and advocate on its behalf in the corridors of power, its voice has been not been anything like as prominent as during the years of New Labour. So what lies ahead for the voluntary sector beyond May 2015? It is to this question that the remainder of this paper turns.

\section{5 onwards: a funding cliff-edge and public service transformation}

The simple answer is that the $2015-20$ period will probably bring more of the same and the Conservative Party's Manifesto pledge to build on the Big Society is symptomatic of this. Through three 'headline' commitments they have said they will extend the National Citizen Service, increase the use of social impact bonds and promote employer support for volunteering, none of which represent anything new in policy terms. Reading across the main parties' manifestos is it clear that radical voluntary sector focussed policy will not be a feature of any political party's legislative programme yet they all propose to cut public spending still further. Granted, the Conservative party's economic plans will mean deeper and more far reaching cuts than Labour or the Lib Dems, but that will provide little comfort for voluntary organisations operating on the frontline of service delivery with the most marginalised people or in the most deprived neighbourhoods. For this group of typically small or medium-sized locally focussed organisations the next five years are likely to be characterised by the consistent possibility of a funding cliff edge.

However, if you scratch beneath the surface at a local level the seeds of significant change are apparent. Most local authorities are in the midst of significant public service transformation and the re-organisation and integration of health and social care continues apace. A common theme across these programmes of local public service reform is a shift towards services that focus on prevention and early intervention. This means redesigning existing services and commissioning new ones in order that the public sector and its partners intervene before something becomes a problem, and respond sooner once a problem has emerged. It is also arguably where a large proportion of the voluntary sector's strengths lie and, as such, presents an opportunity for socially innovative and locally responsive organisations to play a central role in the transformation process and there are plenty of examples of where this already happening. For example, in Rotherham, the Social Prescribing Service, an innovative co-produced partnership between the voluntary sector and statutory health bodies, is providing vulnerable people with long-term health conditions with a clear pathway and support to access community level services that aim to promote greater independence and reduce demand in urgent health and primary care services. A key feature of the 
service is devolution of service-level commissioning decisions to the local voluntary sector infrastructure organisation who undertake a rolling programme of 'microcommissioning' to identify services that meet patients' needs (Dayson et al., 2013). The initial evidence from social prescribing in Rotherham is highly promising. Patients who have accessed the service have demonstrated reductions in unplanned secondary care use of around 20 per cent over a 12 month period alongside significant improvements in their mental health, well-being and independence, and reductions in social isolation (Dayson and Bashir, 2014).

The idea that the voluntary sector should be in embedded in health and social care pathways is gaining traction in other areas too. In Doncaster, for example, a commitment to grant funding by statutory bodies for different levels of 'community innovation' is embedded in its approach to health and social care integration through the Better Care Fund, with a view to enabling new 'universal and community level approaches' to supporting vulnerable people to be developed as part of an integrated social care pathway. Where these services are proven to work there is the possibility for them to be embedded in mainstream service provision. Similarly, in Stockport, a radical new approach to contracting is seeking to develop an 'alliance' of voluntary sector providers, funded through a single contract, to deliver a Targeted Prevention Pathway for people with multiple and complex needs across the borough.

However, at the moment these examples are the exception rather than the rule, and are each being delivered within a wider context of reductions to voluntary sector grants and contracts in these areas. In addition, there are plenty of places where the voluntary sector has been more or less excluded from the transformation agenda and a counter argument could be made that transformation is simply a vehicle for additional public sector cuts. In Greater Manchester, where the transformation agenda is amongst the most advanced, concerns have been raised about the ability of many VCOs to mediate a range of tensions and expectations associated with transformation against the backdrop of welfare retrenchment and public sector austerity (Rees and Rose, 2015). The challenging operating environment facing the voluntary sector across the UK was reflected in the National Coalition for Independent Action's recent Inquiry into the Future of Voluntary Services (NCIA, 2015), which painted a particularly bleak picture for the voluntary sector in many areas, and highlighted the plight of many voluntary organisations clearly struggling close to or at the funding cliff-edge. The challenge for local statutory bodies and, importantly, whichever party or combination of parties gains power in May, will be to identify examples of good practice and enable learning to be transferred and new service delivery models developed across the UK. If this occurs in enough places and at sufficient scale, the prospects for the voluntary sector over the next five years and beyond might not be as bleak as the current storm clouds suggests.

\section{Conclusion}

This short commentary has distilled the author's own reflections on how the past five years of Conservative-Liberal Democratic Coalition have affected the UK voluntary sector and posited some thoughts about the prospects for the sector in the aftermath of the upcoming General Election. What is clear is that the next five years may prove just as challenging for the sector as those that preceded it. But there is small cause for optimism, particularly where the sector can prove itself as a source of innovative and effective preventative services, and where strong local partnerships enable more voluntary and community organisations to play a central role in the public transformation agenda. 
* Correspondence Address: Chris Dayson, CRESR, Sheffield Hallam University, Unit 10, Science Park, Howard Street, Sheffield, S1 1WB. Email: $\underline{\text { c.dayson@shu.ac.uk }}$

\section{References}

Crowe, M., Dayson, C. and Wells, P. (2010) Prospects for the third sector. People, Place and Policy Online, 4, 1, 29-32.

Dayson, C and Bashir, N. (2014) The social and economic impact of the Rotherham Social Prescribing Pilot: Main Evaluation Report. Sheffield: CRESR, Sheffield Hallam University.

Dayson, C., Bashir, N. and Pearson, S. (2013) From dependence to independence: emerging lessons from the Rotherham Social Prescribing Pilot. Sheffield: CRESR, Sheffield Hallam University.

NCIA (2014) NCIA Inquiry into the Future of Voluntary Services: Fight or Fright Voluntary Services in 2015- A Summary and Discussion of the Inquiry Findings. Available online at: http://www.independentaction.net/wpcontent/uploads/2015/02/NCIA-Inquiry-summary-report-final.pdf [Accessed: 02/04/15].

NCVO (2014) The UK Civil Society Almanac 2014. London: NVCO. Available online at: http://data.ncvo.org.uk/a/almanac14/overview-2/ [Accessed: 02/04/15].

Rees, J. and Rose, N. (2015) New 'new localism' or the emperor's new clothes: diverging local social policies and state-voluntary sector relations in an era of localism. Voluntary Sector Review, 6, 1, 81-91.

Trussell Trust (2014) The Trussell Trust's UK foodbank network. Salisbury: The Trussell Trust. 


\title{
Urban planning dilemmas: where next?
}

\author{
Karen Escott* \\ Sheffield Hallam University
}

The new UK parliament will be met with a number of urban planning challenges. Uppermost in national headlines is the delivery of new and affordable housing, particularly in areas where shortages are at crisis point. Secondly environmental sustainability and the impact and mitigation of climate change are concerns for governments globally. Thirdly increasing pressures to address growing spatial inequality are a timely reminder of the importance of planning in the interests of the public 'good' underpinned by strong values for 'just' cities (Fanstein, 2011). Fourthly the need to retain the UK's position in relation to other European cities suggests that investment in strategic infrastructure and wider urban renewal remain high priorities for planning. Finally all political parties support the notion that local communities have a strong stake in their future development yet the extent to which conflicts between interested groups can be resolved through local rather than strategic planning is often overlooked. Underpinning these challenges is a wider debate about the planning system's role in leading and regulating urban development.

In 2010 the Coalition Government introduced radical changes to what they claimed to be an inefficient, complex and over centralised planning system responsible for slowing down development. Previous policies were replaced by the National Policy Planning Framework (NPPF) which not only simplified planning and removed the strategic regional tier but also introduced an ideology centred on economic growth and 'Iocalism' (DCLG, 2012). The NPPF's 'presumption in favour of sustainable development' has in practice been very much open to interpretation. Severe public spending cuts and planning policy changes have meant that local authorities have been expected to take on an enabling rather than a proactive leadership role and neighbourhood planning has become an outlet for the Coalition's view that power should go to the people rather than to local authorities (TSO, 2011). At the same time the influence of the UK property sector has increased with local authorities often finding themselves on the back foot as obligations on developers prove difficult to implement. Deregulation of planning controls and the sale of public assets has encouraged private speculation in particular types of land and buildings. For some localities this has led to inflated housing values lessening the likelihood of meeting affordable housing targets.

Planning policy is problematic in a number of key areas. The Coalition's focus on economic growth reflects a private sector oriented approach. The establishment of Local Enterprise Partnerships as the key delivery vehicle and a series of initiatives including Enterprise Zones which represent a 'trickle down' approach to job creation have been decidedly unclear in terms of local benefits. The dominance of a public private partnership model is also evident in the Planning Inspectorate's national infrastructure plan for transport, energy and airports. Recent concerns about the 
consideration of environmental and social issues as secondary issues and lack of transparency in the planning process bring into question the NPPF's definition of 'sustainable development', suggesting that our urban areas are not being planned as effectively as they might be for the $21^{\text {st }}$ century. Added to this labour market demand and supply issues embedded in previous regeneration policies are largely missing at a time when the UK jobs gap and labour market inequality is worsening (Clayton et al., 2014; Lanchester, 2015). The polarisation of jobs and 'spatial entrapment' experienced by some communities suggests little policy clarity about planning for effective economic and social sustainability at the local level (Hanson and Pratt, 1995). Investment in public services including health, education and care to support people into employment is a key omission in recent job creation debates.

The second contested area for planning involves the longstanding debate over community involvement which took a new direction with the Localism Act and the introduction of 'neighbourhood planning' (TSO, 2011). The potential for thousands of neighbourhoods to have their own plans whilst many planning authorities are being forced to outsource services raises important questions about the effectiveness of a plan making system with some communities being better at 'planning' than others. A lack of clarity about how the commercial viability focus of the NPPF is played out locally is also emerging as a challenge. The potential for significant neighbourhood benefits through planning gain and the Community Infrastructure Levy suggests a need to strengthen the strategic planning framework with publicly accountable plan led development addressing local needs, including those of the least able to participate.

Lastly and perhaps most importantly environmental sustainability and climate change mitigation remain major planning priorities. There are divisions across the political parties about how much to invest and how far to go but with the UK lagging behind many European cities green energy and green jobs will be key to future urban development. Contested carbon reduction targets, energy cost issues and protracted wind farm and fracking inquiries have diverted attention away from most parties having strong energy and conservation policies prioritising environmental concerns. Housebuilding pressures and proposals to build new settlements including urban extensions and new towns on green fields and green belts will continue as key areas of debate into the next parliament (Lyons, 2014). Brownfield first policies where new developments are built on land previously used for commercial or industrial purposes are reappearing as a priority but new designations of 'green' are being introduced by default following a period where green infrastructure planning has been overlooked as a priority. The value attached to high quality urban design has also been challenged in many developer led proposals with the cost versus quality debate a common feature in development where economic viability is uppermost. Thus strategic masterplanning and urban containment measures need to feature in the policy debate along with inclusive design and innovative schemes integrating housing, access and local services (Design Council, 2015). 'Meanwhile' and work/live spaces are areas for creative planning as the use of vacant buildings and technological innovations result in new settlement forms and use of space.

Planning ideology needs to move away from the current emphasis on economic growth and the commercial interests of the property market. A true understanding of the dynamics of localities which includes social and environmental factors should be at the forefront of strong urban planning agendas. The current definition of sustainable development needs to be reviewed if this wider understanding is to be achieved. Plan led development with publicly accountable local leadership underpins planning's success in many parts of Europe suggesting that UK governments must allow planning to deliver as well as enable development. Pro-localist planning needs to recognise the important role of local government and the strategic sub-national tier in addressing 
growing economic and spatial inequalities. Financing of planning for the 'public' good underpinned by investment financed by taxes on for example undeveloped land, empty properties, new buildings and not least some sort of 'mansion' tax and community investment scheme could provide much needed added support to deprived areas.

* Correspondence Address: Karen Escott, CRESR, Sheffield Hallam University, Unit 10, Science Park, Howard Street, Sheffield, S1 1WB. Email:k.escott@shu.ac.uk

\section{References}

Design Council CABE (2015) Inclusive Design Hub https://www.designcouncil.org.uk/projects/inclusive-design-hub-builtenvironment

Clayton, N., Willams, M. and Howell, A. (2014) Unequal opportunity; how jobs are changing cities. London: Centre for Cities.

DCLG (2012) National Planning Policy Framework. London: DCLG.

Fanstein, S. (2011) The Just City. New York: Cornell University Press.

Hanson, S. and Pratt, G. (1995) Gender, work and space. London: Routledge.

Lanchester, J. (2015) The robots are coming. London: Review of Books.

Lyons, M. (2014) The Lyons Housing Review. London: Labour Party.

TSO (2011) The Localism Act 2011. London: The Stationary Office. 


\title{
Regional development: a casualty of the general election?
}

\author{
Steve Fothergill* \\ CRESR, Sheffield Hallam University
}

That the UK still has big regional economic disparities is beyond question. In the early part of 2015, two reports have confirmed that old, familiar problems are still very much part of the economic landscape.

The first report, from the Centre for Cities (2015), looked at trends over the ten years up to 2014 and found that the cities north of a line from the Severn to the Wash have experienced far slower employment growth than those to the south. The second report, from the Industrial Communities Alliance (2015), looked specifically at the recovery from the 2008-09 recession and found that the upturn has been far more modest in older industrial Britain than in London and the South East.

Characterising Britain's economic disparities as a 'North-South divide' is of course a simplification, but it contains more than a grain of truth. It is surprising, therefore, that regional economic policy - that is, efforts by Westminster to achieve a better balance of growth across the UK regions - looks likely to be one of the casualties of the general election, whatever the outcome. The root cause is the popular confusion between, on the one hand, the devolution of power and, on the other, the promotion of jobs and growth in less prosperous parts of the country.

The outcome of the Scottish referendum gave new impetus to devolution, not just for Scotland but also for Wales and for England. But in truth the momentum had been building for some while. For the Conservatives, the Heseltine review (2012) called for the devolution of powers and funding streams to English municipalities and has underpinned the subsequent proliferation of City Deals and the allocation of Local Growth Fund monies to Local Enterprise Partnerships (LEPs). For Labour, the Adonis review (2014) trod a similar path, calling for the further decentralisation of funding from Whitehall to all English local authorities, working together as "combined authorities' across city regions and counties.

Pretty much whatever the result of the General Election, we can therefore expect to see more budget lines devolved to Scotland and Wales, and to groups of English local authorities. This is music to the ears of local politicians.

The assumption, of course, is that by devolving powers and funding streams, jobs and growth will be higher than would otherwise be the case and economically lagging areas will begin to catch up. This is, unfortunately, far from obvious.

For a start, there is no new money on the table. In fact, if austerity continues there could actually be less money handed over to regions and local areas than is currently spent in these places by Whitehall. Then we have to ask whether, say, funding a new road or apprenticeship scheme via a combined authority is really much different to having the same road or apprenticeship scheme paid for directly by Whitehall. There is 
really only likely to be a net gain - to the UK as a whole and to the local area - if the quality of decision making is so much better away from Whitehall. There may be something in this, but the benefits are largely unproven and possibly modest.

The big loser is likely to be regional economic policy. Westminster and Whitehall have traditionally taken responsibility for promoting a better distribution of economic activity across the UK as a whole. The aim has been to narrow gaps in unemployment and GDP per head between the best and worst performing areas, and to bring into use idle resources in the weakest local economies.

Under the Coalition Government, the Regional Growth Fund (RGF) has been the key instrument in England. This provides financial support for projects that create or protect jobs in less prosperous parts of the country. RGF exploits the leeway under EU State Aid rules and draws on the Assisted Area map - just renewed for 2014-20 which identifies the less prosperous parts of the UK where more generous aid to companies is allowed. All RGF funding has been allocated by competitive bidding, and later rounds have been targeted exclusively at the private sector.

There is actually little new in the Regional Growth Fund. In England, it builds directly on the foundations of pre-2010 schemes providing investment aid to companies. These schemes date back continuously to the 1960s and have been known at various times as Grants for Business Investment (GBI), Selective Finance for Investment in England (SFIE), Regional Development Grants (RDG) and Regional Selective Assistance (RSA). Indeed, Scotland's equivalent scheme is still known as RSA. RGF represented a substantial boost in funding - $£ 3.2 \mathrm{bn}$ over six bidding rounds to 2014 - compared to its immediate predecessor $\mathrm{GBI}$, which provided just $£ 428 \mathrm{~m}$ in grants between 2004 and 2010, though RGF fell some way short of fully offsetting the abolition of England's Regional Development Agencies, which at their peak spent around $£ 2$ bn a year on infrastructure and business support. On a per capita basis, the North East of England has received forty times as much in RGF funding as the South East, which is to be expected and welcomed given the relative strength of the two regions' economies.

RGF does deliver additional jobs, as the National Audit Office (2014) has concluded. There are also rigorous efforts by Whitehall to police the 'additionality' principle - that financial support is only given where the project would otherwise have not gone ahead, or only gone ahead on a smaller scale or in a different location.

RGF is in the firing line because as a scheme run centrally by Whitehall, with national priorities and national rules, it doesn't sit easily alongside the devolution of funding to local areas. The Conservatives have made no commitment to renew RGF funding in the next Parliament - for them, there is a whiff of RGF having being seen as an emergency response to the recession. For Labour, RGF has the further handicaps of being seen as an invention of the Coalition and as having been slow to take off (which was true, but the appropriate administrative structures in the Department for Business Innovation and Skills (BIS) are now firmly in place).

Worryingly, the RGF budget line could be simply divided up among England's 39 LEPs (or city regions, or combined authorities) which could mean that places such as Berkshire, Surrey and Suffolk ended up getting a share of monies that once went to less prosperous places in the North. Worse still, the LEPs (or city regions, or combined authorities) could be expected to run replacement schemes which they so clearly lack the capability to police.

* Correspondence Address: Professor Steve Fothergill, CRESR, Sheffield Hallam University, Unit 10, Science Park, Howard Street, Sheffield, S1 1WB. Email: natsec@ccc-alliance.org.uk 


\section{References}

Adonis, A. (2014) Mending the Fractured Economy. London: Policy Network. Centre for Cities (2015) Cities Outlook 2015. London: Centre for Cities.

Heseltine, M. (2012) No Stone Unturned: in pursuit of growth. London: HM Treasury.

Industrial Communities Alliance (2015) Whose Recovery? How the upturn in economic growth is leaving older industrial Britain behind. Barnsley: Industrial Communities Alliance.

National Audit Office (2014) Progress report on the Regional Growth Fund. London: National Audit Office. 


\title{
The 2015 general election and the impending crisis in local public services
}

\author{
Tony Gore* \\ CRESR, Sheffield Hallam University
}

Of the many euphemisms coined by the post-2010 Coalition government, perhaps 'public service reform' sounds the most innocuous, and with its implications of improvement one that should garner widespread support. The reality, of course, has been very different. The term has effectively acted as a decoy for the swingeing expenditure cuts imposed on local authorities across the UK, but especially in England, where central control over council budgets has become tighter than ever. Thus, between 2011/12 and 2014/15 there has been a 33 per cent reduction in real terms in local authority expenditure allowances, to be followed by a further ten per cent real terms cut for the current 2015/16 financial year (Local Government Association, 2014). Moreover, these cuts have not been shared equally by all councils, with those in more disadvantaged areas typically more severely hit than those covering relatively affluent turf (Hastings et al., 2015). Over here as well as in the US, therefore, "the austerity drive....isn't really about debt and deficits at all; it's about using deficit panic as an excuse to dismantle social programs...." (Krugman, 2012, quoted in Peck, 2012).

Geographical variation in the impact of cuts has been mirrored by the differing mixes of response that local authorities have adopted to manage the severe loss of resources. In broad terms, following the formulation devised by Hood (2010), there have been two main approaches:

- Resetting recent reforms: this continues but recasts 'new public management' and related public administration approaches in the shadow of austerity, including new or higher charges for the use of services; rationalisation to just a core service (including reduced opening hours); deferral of repairs, renewal and replacement; squeezing out yet further efficiency savings via higher worker productivity; and 'last minute' intervention at or immediately after the point of collapse.

- System redesign: this involves even more radical models of provision, including leaner privatisation arrangements; encouragement of community-based operation and volunteer staffing; levering more resources through business partnerships and other fiscal arrangements; divestment of assets and dipping into reserves; and shared and collaborative provision with neighbouring authorities and other public agencies. However, there are limits to such inventiveness, imposed either via existing restrictions (such as the use of Right to Buy receipts) or by closure of loopholes which local authorities have managed to exploit for a short time. 
To date, the third scenario of complete abandonment of certain services (characterised by Hood (2010) as 'East of Suez moments') has not been invoked to any great degree. Given the clearly short-term nature of most of the solutions listed above, though, this point may not be too far away. According to the Local Government Association's analysis, if the current approach continues there will be a $£ 5.8$ billion 'black hole' in local authority finances by the end of $2015 / 16$, forecast to rise to $£ 14.4$ billion by 2020 . This would be the equivalent of a 46 per cent decrease in resources available in real terms since 2010/11 (Local Government Association, 2014). Its conclusion is that

...the current funding system is broken and a radical overhaul in the way services are provided and paid for is required across the entire public sector. (Local Government Association media release, July 2013).

The ever-escalating demand for adult social care amongst an ageing population (again likely to fall disproportionately on certain councils) is likely to combine with the decreasing reach and potentially impaired quality of a range of other local services to impose an increased burden on other non-local authority policy domains such as the health service, prisons and the already creaking welfare system. More prosaically, road users across the country are all too familiar with the 'pothole epidemic', with one estimate suggesting that, if joined together, such defects would equate to an area twice the size of the Isle of Wight (Press Association, 2013), and the cost of outstanding remedial work in England and Wales estimated at $£ 12$ billion (BBC News, 2014).

In the face of this impending crisis it should be a fair assumption that local public services will act as one of the key terrains over which the 2015 General Election is fought. However, on the evidence so far that would be over-egging the pudding. Certainly what might be described as 'local policy domains' have received attention, but only a few (such as public transport) have been couched in the role that councils might play. Thus, housing tends to be portrayed as a market issue, at least by the two biggest parties, rather than a public service; and adult social care is subsumed in emotive debates about the National Health Service.

At the same time, that is not to say that the financial nub of the difficulties facing local authorities is being ignored. Rather, the whole question of what level and quality of local service provision we want as a nation is generally seen as subservient to the ever-looming spectre of austerity politics, and its twin relatives, available resources and affordable expenditure. Thus, for the Conservative Party the direction has already been set. They are committed to sticking to their fiscal plan for reaching an ultimate breakeven point in public finances. All else has to fit into this mantra, even to the point of criticising the closure of tax loopholes and better policing of tax avoidance on the grounds that they will only produce a marginal increase in state revenues. In other words, a post-2015 Conservative regime (or Conservative-led coalition) will bring more of the same, its revanchist state approach paring local budgets to the bone whilst still expecting delivery organisations to meet standards and targets. At the same time the promise is to devolve more control (over ever-dwindling resources) to constituent parts of the UK, including sub-national formations within England. This theme is discussed in more detail later in the article.

In many ways the local expenditure cuts and inventive local authority responses to managing them over the last five years have in effect established a new benchmark for future public service proposals. This poses particular restrictions on current Labour Party thinking in this arena, in which its preferred 'relational state' model of empowering citizens and localities to provide the services they require is heavily 
constrained by its promise to keep costs under strict control. Its quest to make the tax system more equitable, whilst also generating a sufficiently large increase in revenue to make a real difference to public service delivery, runs the risk of renewed labelling as the 'tax and spend' party. Thus, a Labour government may give itself some marginal room for manoeuvre as far as public services are concerned, but this may just postpone the tipping point. As for a Labour-led coalition, the prospects are likely to vary depending on which of the smaller parties it can agree to do a deal with.

Indeed it is amongst these increasingly influential 'fourth voices' that recognition of the impending crisis in local services, along with any radical plans about how to address it, can be found. Thus, the Green Party is committed to increasing resources and providing greater powers to local bodies, encompassing a much broader spectrum of collective and community-based organisational forms for ownership, planning and delivery than just the standard local authority. It is less clear exactly where the extra money required would come from, although there is likely to be a tie-up with some form of tax on carbon. The Scottish Nationalist Party, on the other hand, is quite clear that it would use the money saved from alternative cuts such as the unlikely scrapping of the Trident replacement to boost local authority finances as a means of restoring public service levels. The consequent irony of the English acting as the ascetic penny-pinchers and the Scots cast by their denigrators as the profligate spendthrifts is just one of the delicious by-products of our contemporary fragmented politics.

For its part the UK Independence Party is even more wedded to the idea of curbing local state power, and looks as if it would go even further than the Conservatives in cutting back expenditure. Although little detail has yet emerged in terms of its proposals, it is doubtless working on ways in which local authority areas with the greatest concentrations of immigrants can be doubly penalised. As for the Liberal Democrat Party, its enduring localist roots mean that it places the emphasis on local control rather than fiscal wherewithal as the key feature of public service provision. Thus, devices such as 'devolution on demand' for collaborative council structures and widened rights for community organisations to operate services receive emphasis, with no mention of halting or even reversing the current parsimonious trajectory.

To be fair, all parties make strong statements on devolution of power, whether this involves responsibility for additional policy domains for the three national parliaments or more discretion over spending by sub-national assemblages within the four countries of the UK. As with public service reform, however, there is a lot of rhetoric associated with these promises; as Marlow (2015) has commented, "the devil is in the lack of detail". For example, it is not clear how continuing with City Deals in their present form will provide city regions with any degree of autonomous decision-making, still less help to build a "Northern Powerhouse" as promised by the Conservatives. In essence City Deals are funding agreements for packages of specific projects, many of which will have already been on the stocks, but possibly postponed due to expenditure cutbacks. Moreover, for the most part they cover policy domains over which local authorities already have extensive powers, such as economic development, business support, housing and transport. It is only in areas such as skills and employability that any new responsibilities have been afforded, albeit only small-scale targeted interventions, rather than anything more far-reaching.

Indeed, it could be argued that councils have had far more discretion in where to administer the expenditure cuts over the last five years, rather than the much trumpeted 'new freedoms' afforded by City Deals. Add to this other Coalition changes such as the presumption in favour of development in the planning system, and it is clear that much of what is on offer in terms of local autonomy represents little more than stale crumbs from the Whitehall table. Admittedly, the more interventionist parties such as Labour, the Greens and the SNP do appear to promise greater discretion over 
funding allocations at local level, with the former quoting a figure of $£ 30$ billion (about a quarter of the total) as expenditure over which responsibility would be devolved to 'city and county regions'. What policy areas this would cover remains unclear, however, and the commitment should also be read in the context of the earlier statement that under a Labour government "there would be (further) cuts in spending" (Labour Party Manifesto, 2015: 17). Moreover, it still remains unclear how any post-2015 government might go about sorting out what Durham leader Simon Henig has called the "dog's breakfast" of current asymmetrical devolution in England (Fearn, 2015; Public Service Intelligence, 2014).

The depressing reality for English devolutionists may well turn out to be a series of additional spending allowances to selected areas, with the most generous going to those which meet certain arbitrary criteria (such as having an elected mayor), rather than anything more fundamental. The likelihood is that these allowances would actually be heavily controlled by central government but with local commissioners (in whatever collaborative format they emerge) responsible for picking up the pieces and shouldering the blame should things go wrong. Nothing that any party has said or done so far in the campaign could lead one to expect a dilution in the 150 year old tradition of centralised and paternalistic decision-making in the UK.

* Correspondence Address: Dr Tony Gore, CRESR, Sheffield Hallam University, Unit 10, Science Park, Howard Street, Sheffield, S1 1WB. Email: t.gore@shu.ac.uk

\section{References}

BBC News (2014) Estimated road repairs cost rises to $£ 12 b n$, survey says. 3 April 2014, http://www.bbc.co.uk/news/uk-26862992

BBC website (2015) General Election 2015, Policy guide: Where the parties stand. http://www.bbc.co.uk/news/election/2015/manifesto-guide

Fearn, H. (2015) The 'super-council' leader making friends across the North-East. The Guardian, $25 \quad$ March 2015 http://www.theguardian.com/society/2015/mar/25/super-council-north-eastdurham-simon-henig

Hastings, A., Bailey, N., Bramley, G., Gannon, M. and Watkins, D. (2015) The Cost of the Cuts: The Impact on Local Government and Poorer Communities. York: Joseph Rowntree Foundation. http://www.jrf.org.uk/sites/files/jrf/CostofCuts-Full.pdf

Hood, C. (2010) Reflections on Public Service Reform in a Cold Fiscal Climate. London: 2020 Public Services Reform Trust.

Krugman, P. (2012) The austerity agenda. New York Times, 1 June 2012, p. A27.

Local Government Association (2013) "£14.4 billion funding blackhole threatens to swallow public services." Media release, 4 July 2013. http://www.local.gov.uk/media-releases//journal_content/56/10180/4053260/NEWS

Local Government Association (2014) Future Funding Outlook 2014: Future funding outlook for councils to 2019/20. London: Local Government Association.

Marlow, D. (2015) Leadership and governance of local growth - pre-general election round up. Policy Briefing, London: Local Government Information Unit.

Peck, J. (2012) Austerity urbanism: American cities under extreme economy. City: analysis of urban trends, culture, theory, policy, action, 16, 6, 626-655. DOI: 10.1080/13604813.2012.734071

Public Service Intelligence (2014) Devo-City: A short guide to Britain's devolving city regions in words and data. Birmingham: Public Service Intelligence Ltd. 
p. 86. Election Commentaries

Press Association (2013) Potholes could swallow Isle of Wight: Freedom of information figures reveal one pothole for every mile of UK road and councils paying out $£ 2.5 \mathrm{~m}$ for vehicle damage. The Guardian, 9 October 2013. http://www.theguardian.com/world/2013/oct/09/potholes-isle-of-wight 


\title{
Migration policy: stuck in a rut?
}

\author{
David Robinson* \\ CRESR, Sheffield Hallam University
}

\begin{abstract}
A popular and political consensus has emerged out of the heated debate surrounding the issue of migration about the need to reduce the number of migrants settling in the UK. Immigration is considered to be 'out of control' and the country is portrayed as paying a heavy price, socially, culturally and economically. Much has been made of the Coalition Government's failure to deliver on David Cameron's promise to reduce net migration to tens of thousands each year. This target was never going to be delivered, but the tone that it set was very much in tune within the national mood. One-third of people view immigration as one of the most important issues facing the UK today, making immigration the second most important issue as measured by the IPSOS MORI issues index. In response, Coalition policy has focused on reforms to the immigration system designed to tighten controls on non-EEA migrants and curtail the rights of EU migrants, which were presumed to make the UK an attractive destination. The prospect appears to be more of the same for the next Parliament.
\end{abstract}

The direction of travel on migration policy tends to be determined by the position adopted in relation to three key considerations. First, there is the issue of the social and cultural implications of migration. Currently, the dominant perspective is that migration changes places, promotes disharmony, challenges 'our' way of life, risks undermining 'British' values and threatens stability and cohesion. The possibility that benefits might flow from the more cosmopolitan spaces created by migration that serve to enrich cultural life is rarely acknowledged or articulated in popular debate. Migration is deemed to have social and cultural costs. Second, there is the question of economics. Here the situation is more confused and contested. There is an entrenched view that migrants are a drain on public services and resources, epitomised in stories about health and benefit tourism, which government has sought to propagate and address. At the same time, migration is recognised, particularly by business and HM Treasury as providing a source, of cheap, skilled labour, which supports efficient delivery of public services (the NHS being a prime example), minimises the costs and maximises the profits that private business contributes to GDP. Third, there is the humanitarian issue. This might be interpreted as relating to the moral and legal duty of the UK to protect people fleeing persecution and, as part of this commitment, to provide a fair and speedy asylum process and to respect the human rights of people seeking asylum. This agenda is increasingly viewed as secondary to the need to clamp down and control in order to ensure that the UK is not a 'soft touch' for 'bogus' asylum seekers.

There is little sign of an alternative narrative arising with the strength required to uproot these entrenched perspectives. The proposals laid out in the manifestos of the three main UK-wide political parties and UKIP are consistent with this dominant account, despite some variations in tone and emphasis. First, immigration policy looks 
set to remain socially conservative, with the key focus being on cost concerns and the need to restrict numbers. The UKIP manifesto makes reference to an "unprecedented influx", which has "had significant consequences on our economy, our public services, our culture and our environment" (p.11). The Conservative manifesto talks about controlled immigration and points to the pressure on schools, hospitals and transport, and the social pressures that arose as a result of the last Labour governments "open border" policy (p.29). The Labour Party manifesto assumes a gentler tone, referring to public anxiety about its effects on wages, on our public services, and on our shared way of life (p.49). In response, the focus is on the need for stronger border controls, new visa regulations and a crack down on illegal immigration. The Conservative Party manifesto also renews the commitment made in 2010 to reduce annual net migration to the tens of thousands.

There are few proposals to support integration, beyond the presumption evident in the UKIP manifesto that reducing immigration will produce more harmonious, integrated communities. This continues the tendency for policy to be quick to blame migrants for not integrating into British society but slow to support the integration process. The failure of migrants to speak English is often cited as indicative of unwillingness to integrate. The Conservative manifesto recognises being able to speak English as a fundamental part of integrating into British society and points to the introduction of new language tests for migrants and a reduction in spending on translation services (p.31). The Conservative and Labour Party manifestos commit to strengthen social integration by requiring that all people working in public services, in public facing roles, speak English. However, all the evidence points to a desire and willingness amongst new migrants to learn English, in recognition of the fact that English language skills are fundamental to operating independently in UK society. Yet, free access to ESOL training (English for Speakers of Other Languages) has been limited to people on 'active' benefits, thereby excluding large numbers of migrants including full-time parents, people in low-paid employment, people with disabilities and older people.

Another notable silence relates to the help for local communities managing the process of change driven by migration, which can prove disorientating for existing communities and challenging for service providers. The only offer of help and assistance is a commitment from the Conservative Party to introduce a new Controlling Migration Fund (p.31), intended to ease pressures on services and to pay for additional immigration enforcement. Local services therefore look likely to have to continue managing the challenges of responding to rapid population change and a shifting profile of local need, and deal with the tensions that sometimes arise between new arrivals and settled populations, all within the context of austerity and cuts.

Second, immigration policy looks set to remain economically liberal, with a focus on balancing the benefits of high skilled migration with the need to limit low skilled migration for social, economic and cultural reasons. All the manifestos recognise the contribution of the 'brightest and best' migrants to the UK economy. The Labour and Liberal Democrat manifestos champion the vital role played by migrant workers to business and the economy and make no reference to a cap on the number of skilled migrants entering the UK. The Conservative and UKIP manifestos recognise the economic benefits of skilled migration but propose a cap on skilled migration, reflecting concerns about social costs. The Conservatives manifesto renews a commitment to a cap on skilled migrants from outside the EU set at 20,700 people per year, which was introduced during the last Parliament. This cap has never been reached since it was introduced and it will be interesting to see whether a Conservative government would be able to hold this line in the face of pressure from business if demand for skilled 
migrant labour rises as the economy grows. UKIP proposes limiting highly-skilled work visas to 50,000 per annum, including those from the EU.

The focus in relation to low skilled migration is squarely on reducing the number of migrants and restricting their rights to public services and benefits. UKIP commits to a five-year moratorium on immigration for unskilled workers, the presumption being that this will enable unemployed people to find work and those in work to benefit from wage growth. The Labour Party also argues that low-skilled migration has been too high and needs to come down, but proposes to address the issue through a new law to prevent the exploitation of migrant workers (which is presumed to undercut local wages and promote reliance on migrant labour) and a ban on recruitment agencies from hiring only from overseas (p.50). The Conservative Party makes a commitment to tougher labour market regulation to tackle illegal working and exploitation (p.31). The Liberal Democrat manifesto stands alone in making no explicit reference to reducing low skilled migration, but is consistent with the other three manifestos in emphasising the need to limit the rights of migrants to various benefits and public services.

Finally, immigration policy looks set to remain largely illiberal in relation to human rights, the focus being on clamping down and controlling - limiting the rights of asylum seekers, refugees and migrants. The manifestos are replete with commitments to limit and restrict the rights of migrants. Moves to deport illegal immigrants and foreign criminals more quickly and restrict legal challenges to immigration decisions are to the fore in the Conservative and UKIP manifestos. However, these manifestos are largely silent on the human rights of migrants, despite evidence that the immigration system far too often compromises rather than protects human rights. An extreme illustration is the detention and enforced removal regime. According to the All Party Inquiry into immigration detention in the UK, 30,418 people entered an immigration detention centre in the UK in 2013. This was more than seven times the number entering detention in Germany in the same year. The Inquiry also reports that the UK is an international outlier in not having a limit on the length of time an individual can be detained for immigration purposes, resulting in some people being detained for a number of years despite having committed no crime. There is no reference to the detention regime or the human rights of asylum seekers and refugees in either the Conservative Party or UKIP manifestos. The Labour and Liberal Democrat manifestos commit to end the indefinite detention of people in the asylum and immigration system, although no specific details are provided, and the Labour manifesto commits to end the detention of pregnant women and of those who have been the victims of sexual abuse or trafficking.

* Correspondence Address: Professor David Robinson, CRESR, Sheffield Hallam University, Unit 10, Science Park, Howard Street, Sheffield, S1 1WB. Email: d.robinson@shu.ac.uk 